\title{
Phylogenetic diversity of mesophilic and thermophilic granular sludges determined by $16 S$ rRNA gene analysis
}

\author{
Yuji Sekiguchi, ${ }^{1,2}$ Yoichi Kamagata, ${ }^{2}$ Kazuaki Syutsubo, ${ }^{1}$ \\ Akiyoshi Ohashi, ${ }^{1}$ Hideki Harada' ${ }^{1}$ and Kazunori Nakamura ${ }^{2}$
}

1 Department of

Environmental Systems

Engineering, Nagaoka

University of Technology,

Kamitomioka 1603-1

Nagaoka, Niigata

940-2188, Japan

2 National Institute of Bioscience and HumanTechnology, Agency of Industrial Science and

Technology, Tsukuba, Ibaraki 305-8566, Japan

\author{
Author for correspondence: Yuji Sekiguchi. Tel: +81258471611 ext. 6313. Fax: +81258479600. \\ e-mail: skgc@vos.nagaokaut.ac.jp
}

The microbial diversity of two types of methanogenic granular sludge, mesophilic $\left(35^{\circ} \mathrm{C}\right)$ and thermophilic $\left(55^{\circ} \mathrm{C}\right)$, which had been treating sucrose/propionate/acetate-based artificial wastewater were compared. $16 \mathrm{~S}$ rDNA clone libraries were constructed by PCR with a prokaryote-specific primer set, and partial sequencing of the clonal 165 rDNAs was conducted for phylogenetic analysis. Of 115 mesophilic granule and 110 thermophilic granule clones sequenced, 19 and $22 \%$, respectively, were phylogenetically affiliated with the domain Archaea, and the remainder in each case were assigned to the domain Bacteria. Within the domain Archaea, the 16S rDNA clones in both libraries showed relatively close relationships with those of methanogens. Within the Bacteria, a major group represented in the mesophilic clone library was the delta subclass of the Proteobacteria $(27 \%)$, in which high degrees of relatedness were observed between the clonal 165 rDNA sequences and those of previously identified syntrophic bacteria and sulfate-reducing bacteria. In contrast, in the thermophilic clone library, the Thermodesulfovibrio group $(19 \%)$, the green non-sulfur bacteria (18\%) and the low G+C subclass of the Gram-positive bacteria (18\%) were predominant. A significant difference between the two libraries was that no clone affiliated with the Proteobacteria was detected in the thermophilic clone library, whereas the Proteobacteria was the most predominant group in the mesophilic clones. Thirty-six and 24 different sequences were found in the mesophilic and thermophilic clones, respectively, suggesting that the microbial diversity of the thermophilic granule was lower than that of the mesophilic granule.

Keywords: 16S rDNA, granular sludge, thermophilic, upflow anaerobic sludge blanket (UASB) reactor

\section{INTRODUCTION}

Granulation of sludge is the most characteristic phenomenon of upflow anaerobic sludge blanket (UASB) reactors, in which micro-organisms form dense aggregates as a result of their self-immobilization property. In these reactors, one pellet of granular sludge is a functional unit which comprises all of the different

Abbreviations: DAPI, 4',6-diamidino-2-phenylindole; MUR, mesophilic UASB reactor; OTU, operational taxonomic unit; TUR, thermophilic UASB reactor; UASB, upflow anaerobic sludge blanket.

The GenBank/EMBLDDBJ accession numbers for the sequences of clones MUG1-TUG24 are AB011293-AB011352. trophic groups of micro-organisms necessary for anaerobic degradation of organic compounds (Lettinga, 1995). In encompassing various competitive and syntrophic associations between micro-organisms, the consortium forms a quite unique microbial ecosystem within several millimetres of an aggregate (Grotenhuis et al., 1991; Harmsen, 1996; Macario et al., 1991; MacLeod et al., 1990; Stams et al., 1989). In the last decade, several micro-organisms in granular sludges have been isolated and characterized (Harmsen, 1996; Stams et al., 1992; Wu et al., 1992). However, cultivation-dependent methods have limitations in elucidating diversity in the microbial ecosystem (Ward et al., 1990), and thus many of the component species may 
remain to be identified. In particular, the microbial community in thermophilic anaerobic processes is poorly characterized.

In recent years, the thermophilic anaerobic digestion process has become an attractive alternative for medium- and high-strength wastewater treatment, because it is capable of accommodating a very high loading rate at reasonable treatment efficiency. However, the thermophilic processes appear to be more sensitive to environmental changes than the mesophilic process (van Lier, 1996), and formation of thermophilic granular sludge is much more difficult than the mesophilic equivalent (Schmidt \& Ahring, 1995; Wiegant, 1986). Consequently, full-scale thermophilic UASB processes are not in routine operation and further studies on the microbial composition of the thermophilic anaerobic community are required to establish stable and highperformance thermophilic processes.

Here, we characterize the microbial communities of two types of methanogenic sludge, mesophilic $\left(35^{\circ} \mathrm{C}\right)$ and thermophilic $\left(55^{\circ} \mathrm{C}\right)$ granules, based on $16 \mathrm{~S}$ rRNA gene analysis.

\section{METHODS}

Operation of UASB reactors. Granules were sampled from two types of laboratory-scale UASB reactor (13 l capacity), i.e. mesophilic (MUR) $\left(35^{\circ} \mathrm{C}\right)$ and thermophilic (TUR) $\left(55^{\circ} \mathrm{C}\right)$. Both reactors had been fed with artificial wastewaters of similar composition comprising mainly sucrose, acetate, propionate and peptone or yeast extract $[4 \cdot 5: 2 \cdot 25: 2 \cdot 25: 1$, chemical oxygen demand (COD)-base] over 2 years operation. The wastewater for MUR comprised $\left(\mathrm{mg} \mathrm{l}^{-1}\right)$ : sucrose, 800 ; sodium acetate, 600 ; propionate, 300 ; peptone, $200 ; \mathrm{NH}_{4} \mathrm{Cl}$, $110 ; \mathrm{Na}_{2} \mathrm{SO}_{4}, 120 ; \mathrm{KH}_{2} \mathrm{PO}_{4}, 150 ; \mathrm{KCl}, 300 ; \mathrm{CaCl}_{2} .2 \mathrm{H}_{2} \mathrm{O}$, $150 ; \mathrm{MgCl}_{2} .2 \mathrm{H}_{2} \mathrm{O}, 400 ; \mathrm{NaHCO}_{3}, 2000$; trace elements as indicated below. The wastewater for TUR comprised (mg $\left.1^{-1}\right)$ : sucrose, 1600 ; sodium acetate, 1200 ; propionate, 600; yeast extract, $200 ; \mathrm{NH}_{4} \mathrm{Cl}, 222 ; \mathrm{Na}_{2} \mathrm{SO}_{4}, 233 ; \mathrm{KH}_{2} \mathrm{PO}_{4}, 11$; $\mathrm{KCl}, 16 ; \mathrm{CaCl}_{2} \cdot 2 \mathrm{H}_{2} \mathrm{O}, 5 ; \mathrm{MgCl}_{2} \cdot 6 \mathrm{H}_{2} \mathrm{O}, 33 ; \mathrm{NaHCO}_{3}, 2000$; trace elements. The trace elements contained in both wastewaters were $\left(\mathrm{mg} \mathrm{l}^{-1}\right): \mathrm{FeCl}_{2}$. $4 \mathrm{H}_{2} \mathrm{O}, 3.93 ; \mathrm{CoCl}_{2} .6 \mathrm{H}_{2} \mathrm{O}, 0 \cdot 17$; $\mathrm{ZnCl}_{2}, 0.07 ; \mathrm{H}_{3} \mathrm{BO}_{3}, 0.06 ; \mathrm{MnCl}_{2} .4 \mathrm{H}_{2} \mathrm{O}, 0.50 ; \mathrm{NiCl}_{2} .6 \mathrm{H}_{2} \mathrm{O}$, $0.04 ; \mathrm{CuCl}_{2} .2 \mathrm{H}_{2} \mathrm{O}, 0.03$; and $\mathrm{NaMoO}_{4} .2 \mathrm{H}_{2} \mathrm{O}, 0.03$. The influent for the reactors, consequently, had a strength of $2000 \mathrm{mg} \mathrm{COD}^{-1}$ for MUR, $4000 \mathrm{mg}^{-C O D ~ ~^{-1}}$ for TUR (volumetric loading rate for MUR is $8 \mathrm{~kg} \mathrm{COD} \mathrm{m}^{-3} \mathrm{~d}^{-1}$ and for TUR is $23 \mathrm{~kg} \mathrm{COD} \mathrm{m}^{-3} \mathrm{~d}^{-1}$; hydraulic retention time for MUR is $6 \mathrm{~h}$ and for TUR is $4.2 \mathrm{~h}$ ), respectively. The $\mathrm{pH}$ of the influent was approximately neutral. The seed sludges were mesophilically digested anaerobic sludge (for MUR) and thermophilically digested anaerobic sludge (for TUR).

DNA extraction. Granules were collected directly from two different sites of each UASB reactor which had been operated for over 2 years, immediately frozen in liquid nitrogen and stored at $-20^{\circ} \mathrm{C}$. Before DNA extraction, frozen granules were slowly thawed, washed gently with phosphate buffer

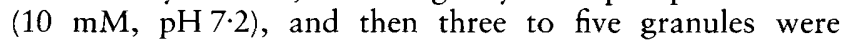
homogenized in extraction buffer $(10 \mathrm{mM}$ Tris $/ \mathrm{HCl}, \mathrm{pH} 7 \cdot 5$, $50 \mathrm{mM}$ EDTA, $0.5 \mathrm{M} \mathrm{NaCl}$ ). The DNA extraction strategy was based on the method of Tsai \& Olson (1991) with some modifications (Ohkuma \& Kudo, 1996). Briefly, after $5 \mathrm{~s}$ sonication, the mixture was incubated in the presence of lysozyme (final concentration $5 \mathrm{mg} \mathrm{ml}^{-1}$ ) for $40 \mathrm{~min}$ at $37^{\circ} \mathrm{C}$. At the end of the incubation, proteinase $\mathrm{K}$ was added to a final concentration of $2 \mathrm{mg} \mathrm{ml}^{-1}$ and incubated at $37^{\circ} \mathrm{C}$ for another $40 \mathrm{~min}$ with occasional agitation. SDS was added to give a final concentration of $1 \%(\mathrm{w} / \mathrm{v})$ and the mixture was agitated gently. The mixture was frozen in liquid nitrogen followed by thawing in a $65^{\circ} \mathrm{C}$ water bath. This step was repeated three times to release a sufficient amount of nucleic acids. For purification of the mixture, an equal volume of phenol (saturated with $10 \mathrm{mM}$ Tris $/ \mathrm{HCl}, \mathrm{pH}$ 8.0) was added followed by extraction with phenol/chloroform $(1: 1)$. Nucleic acids were recovered by addition of an equal volume of 2-propanol and centrifugation for $20 \mathrm{~min}$ at $12000 \mathrm{~g}, 4^{\circ} \mathrm{C}$. The pellets were rinsed with $70 \%$ ethanol and resuspended in $50 \mu \mathrm{TE}$ (10 mM Tris/HCl, pH 8.0, $1 \mathrm{mM}$ EDTA). RNA in the suspension was digested with RNase A (final concentration $50 \mu \mathrm{g} \mathrm{ml} l^{-1}$ ) for $30 \mathrm{~min}$ at $37^{\circ} \mathrm{C}$. Nucleic acids were precipitated with 2.5 vol. $100 \%$ ethanol and 0.25 vol. sodium acetate $(3 \mathrm{M}, \mathrm{pH} 5 \cdot 2)$. Extracted DNA was rinsed with $70 \%$ ethanol and dissolved in TE. Bulk DNA preparations extracted from the granules at two different sites of each reactor were combined for further analysis.

PCR amplification and cloning. Amplification of $16 \mathrm{~S}$ rRNA genes from the purified DNA preparations was carried out by PCR with Taq polymerase (Perkin Elmer) according to the manufacturer's instructions (200 ng template DNA, $1 \times$ Taq polymerase buffer, 2.5 units Taq polymerase, $200 \mu \mathrm{M}$ dNTPs and $100 \mathrm{pmol}$ of each primer in a $100 \mu \mathrm{l}$ reaction volume). The PCR primers used in the amplification were universal primer 530F (5'-GTGCCAGCMGCCGCGG-3'; $\mathrm{M}$ represents A or C, 514-529 Escherichia coli position) and prokaryote-specific primer 1490R (5'-GGTTACCTTGTTACGACTT-3'; 14911509 E. coli position) (Lane, 1991; Weisburg et al., 1991). The reaction conditions were as follows: initial denaturation at $95^{\circ} \mathrm{C}$ for $9 \mathrm{~min}$, followed by 15 cycles of $95^{\circ} \mathrm{C}$ for $1 \mathrm{~min}, 50^{\circ} \mathrm{C}$ for $1 \mathrm{~min}$ and $72^{\circ} \mathrm{C}$ for $2 \mathrm{~min}$. PCR products corresponding to the expected size of amplified rDNA $(1.0 \mathrm{~kb})$ were purified with a GeneClean II kit (Bio 101). To reduce the possible bias caused by PCR amplification, rDNA was amplified in triplicate tubes and these were combined for the next cloning step. The rDNA fragments were cloned into plasmids using the TA cloning kit (Novagen).

Sequencing and phylogenetic analysis. Clonal rDNAs were prepared from randomly selected recombinants and used as template for sequencing. Sequencing was conducted with the 530F primer and PRISM Dye Terminator Cycle Sequencing FS Ready Reaction kit (Applied Biosystems) and an automated sequence analyser (model 377; Applied Biosystems). rDNA sequences with a range of about $500-600$ bases were obtained for all clones. All sequences were checked for chimeric artifacts by the CHECK_CHIMERA program in the Ribosomal Database Project (RDP) (Maidak et al., 1997) and compared with similar sequences of the reference organisms by BLAST search (Altschul et al., 1990). Sequence data were aligned with the CLUSTAL w package (Thompson et al., 1994) and corrected by manual inspection. Phylogenetic trees were constructed by the neighbour-joining method (Saito \& Nei, 1987) with the MEGA package (Kumar et al., 1993). Bootstrap resampling analysis (Felsenstein, 1985) for 100 replicates was performed to estimate the confidence of tree topologies. Identical sequences were recognized by phylogenetic tree analysis and manual comparison, in which completely $(100 \%)$ similar sequences were defined as identical, and used for further phylogenetic analysis as an operational taxonomic unit (OTU). The OTUs were designated MUG1-MUG36 for the MUR granule clones and TUG1-TUG24 for the TUR clones. 
In situ hybridization. Fresh granule samples were homogenized, fixed with $4 \%$ paraformaldehyde in PBS $(0.13 \mathrm{M} \mathrm{NaCl}$ in $10 \mathrm{mM} \mathrm{Na}_{2} \mathrm{HPO}_{4}, \mathrm{pH} \mathrm{7 \cdot 2)}$, and left for $4 \mathrm{~h}$. The samples were dispersed with sonication and immobilized on glass slides coated with Vectabond (Vector Laboratories). For hybridizations, we used the following rhodamine-labelled oligonucleotide probes complementary to specific regions of $16 \mathrm{~S}$ rRNA: (i) EUB338, specific for the domain Bacteria (Amann et al., 1990) and (ii) ARC915, specific for the domain Archaea (Stahl \& Amann, 1991). Hybridizations were performed at $46{ }^{\circ} \mathrm{C}$ for $3 \mathrm{~h}$ with a hybridization buffer $(0.9 \mathrm{M} \mathrm{NaCl}, 20 \mathrm{mM}$ Tris/ $\mathrm{HCl}, \mathrm{pH} 7 \cdot 2,0 \cdot 01 \%$ SDS) containing each labelled probe $\left(5 \mathrm{ng}^{\mathrm{l}} \mathrm{l}^{-1}\right.$ ). Hybridization stringency was adjusted by adding formamide to the hybridization buffer $(5 \%$ for EUB338 and $35 \%$ for ARC 915$)$. After hybridization, the slides were washed at $48{ }^{\circ} \mathrm{C}$ for $20 \mathrm{~min}$ with washing buffer containing the same components of the hybridization buffer except the probes. To enumerate the total cell number in the samples, the samples were stained with $4^{\prime}, 6$-diamidino-2-phenylindole (DAPI) at a final concentration of $5 \mu \mathrm{g} \mathrm{ml}^{-1}$. Over 1000 DAPI-stained cells were counted to determine the ratio of the probe-labelled cells to the total cells.

\section{RESULTS}

\section{UASB reactor performance}

Two laboratory-scale UASB reactors were operated over 2 years and formed well-settling granules adapted at different temperatures but with similar composition of substrate. Mesophilic and thermophilic granular sludges with a mean diameter of 1-2 $\mathrm{mm}$ were obtained after continuous operation of 3 and 7 months, respectively. COD removal of the reactors was $90-97 \%$, and almost all of the COD removed (approximately $95 \%$ ) was converted to methane in soluble and gaseous form. Since influent wastewater contained low concen- trations of sulfate $\left(81 \mathrm{mg} \mathrm{l}^{-1}\right.$ for MUR, $157 \mathrm{mg} \mathrm{l}^{-1}$ for TUR), only a small amount of COD degradation appeared to be attributed to sulfate reduction (approx. $3 \%$ of the total COD removed).

\section{PCR amplification}

PCR amplification of $16 \mathrm{~S}$ rRNA genes was conducted with prokaryote-specific primers, resulting in amplification of the domains Archaea and Bacteria simultaneously. To avoid involving the bias caused by template annealing in PCR amplification (Suzuki \& Giovannoni, 1996), the thermal cycling in PCR was decreased to 15 cycles. Only a single band corresponding to the expected size of amplified DNA (approximately $1.0 \mathrm{~kb}$ ) was observed for both granule DNA preparations on agarose gel electrophoresis. This fraction was used for the construction of $16 \mathrm{~S}$ rDNA clone libraries for the granules.

\section{Overall phylogenetic analysis}

We prepared 115 and 110 clones of $16 \mathrm{~S}$ rDNA libraries for the MUR and the TUR granules, respectively. Among the clones analysed, 37 different sequences (OTUs) were found in the MUR granule library and 24 OTUs in the TUR granule library. Large-scale phylogenetic tree analysis of these OTUs was performed to affiliate the clonal sequences to hitherto-determined groups (Maidak et al., 1997; Woese, 1987; Woese et al., $1990)$. From this analysis, 22 (19\% of the total clones) and $24(22 \%) 16 \mathrm{~S}$ rDNA clone sequences from the MUR and TUR granule libraries were affiliated with the domain Archaea and $92(80 \%)$ and $86(78 \%)$ clones

Table 1. Distribution of $16 S$ rDNA clones detected in the MUR and TUR granules

\begin{tabular}{|c|c|c|c|c|c|c|}
\hline \multirow[t]{2}{*}{ Group } & \multicolumn{3}{|c|}{ MUR library } & \multicolumn{3}{|c|}{ TUR library } \\
\hline & $\begin{array}{l}\text { No. of } \\
\text { OTUs }\end{array}$ & $\begin{array}{l}\text { No. of } \\
\text { MUR } \\
\text { clones }\end{array}$ & $\begin{array}{c}\text { Percentage } \\
\text { of total } \\
\text { clones }\end{array}$ & $\begin{array}{c}\text { No. of } \\
\text { OTUs }\end{array}$ & $\begin{array}{l}\text { No. of } \\
\text { TUR } \\
\text { clones }\end{array}$ & $\begin{array}{c}\text { Percentage } \\
\text { of total } \\
\text { clones }\end{array}$ \\
\hline \multicolumn{7}{|l|}{ Archaea } \\
\hline Euryarchaeota & 3 & 22 & 19 & 3 & 24 & 22 \\
\hline \multicolumn{7}{|l|}{ Bacteria } \\
\hline Green non-sulfur bacteria & 4 & 16 & 14 & 5 & 20 & 18 \\
\hline Thermodesulfovibrio group & 2 & 6 & 5 & 2 & 21 & 19 \\
\hline Synergistes & 1 & 1 & 1 & 1 & 6 & 5 \\
\hline \multicolumn{7}{|l|}{ Gram-positive bacteria } \\
\hline High $G+C$ subclass & 2 & 5 & 4 & - & - & - \\
\hline Low $\mathrm{G}+\mathrm{C}$ subclass & 4 & 8 & 7 & 9 & 17 & 16 \\
\hline Planctomyces and relatives & 5 & 11 & 10 & 3 & 14 & 13 \\
\hline Cytophaga/Flexibacter/Bacteroides & 2 & 9 & 8 & - & - & - \\
\hline Spirochaetes and relatives & 3 & 3 & 3 & - & - & - \\
\hline \multicolumn{7}{|l|}{ Proteobacteria } \\
\hline Delta subclass & 9 & 31 & 27 & - & - & - \\
\hline Green sulfur bacteria & 1 & 2 & 2 & 1 & 8 & 7 \\
\hline
\end{tabular}




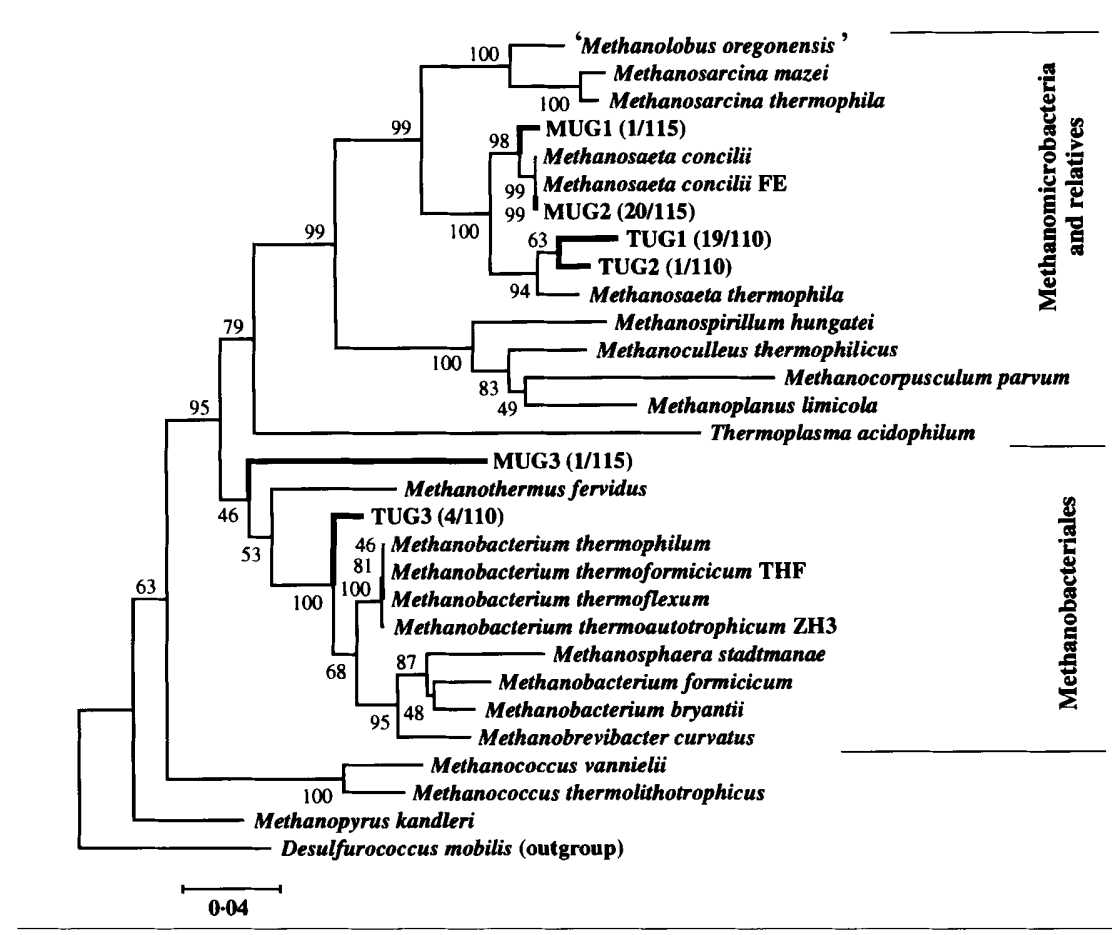

Fig. 1. Phylogenetic tree of the clones among the class Euryarchaeota of the domain Archaea, based on neighbourjoining analysis (Saito \& Nei, 1987) of partial $16 \mathrm{~S}$ rDNA sequences. MUG represents the mesophilic granule clones and TUG represents the thermophilic clones. Numbers in parentheses indicate the frequency of appearance of the completely matched sequences (clones) in the total clones (number of identical clones/number of the total clones). Numbers at nodes represent bootstrap values (Felsenstein, 1985) for the nodes (100 times resampling analysis). Desulfurococcus mobilis is used as the outgroup.

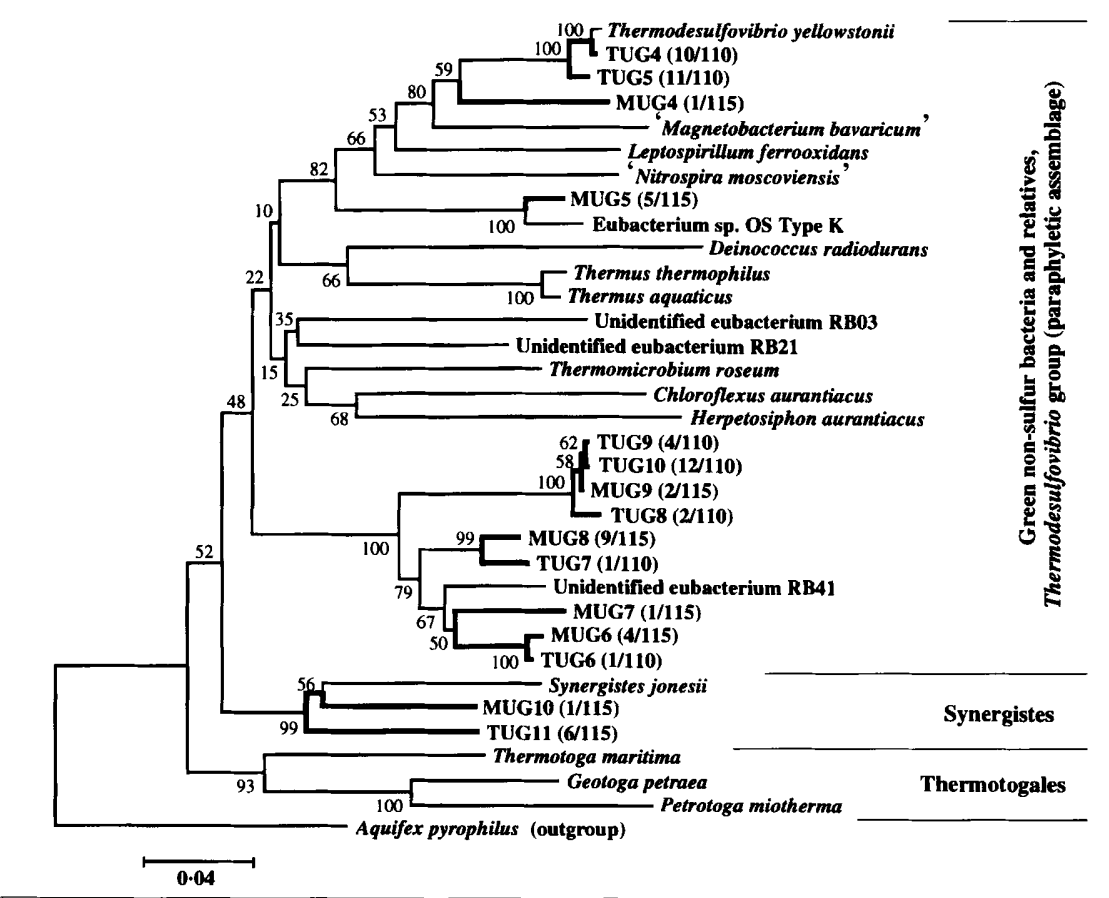

Fig. 2. Phylogenetic tree of the clones among the Thermodesulfovibrio group, the green non-sulfur bacteria and Synergistes of the domain Bacteria, based on neighbourjoining analysis of partial $16 \mathrm{~S}$ rDNA sequences. Synergistes is included in the paraphyletic assemblage in the RDP phylogenetic list (Maidak et al., 1997), but this taxon does not form a clade with that in this analysis. Numbers in parentheses and numbers at nodes are the same as in Fig. 1. Aquifex pyrophilus is used as the outgroup. were assigned to the domain Bacteria, respectively. Only one clonal sequence in the MUR granule library could be recognized as a chimeric artifact.

We also performed in situ hybridization counts for both sludges using Archaea (ARC915)- and Bacteria (EUB338)-specific probes (Stahl \& Amann, 1991; Amann et al., 1990). By this approach, it was found that Archaea cells in the MUR and TUR granules accounted for approximately 37 and $42 \%$, respectively, of the total
DAPI counts (data not shown). Bacteria cells accounted for 45 and $43 \%$ of the DAPI counts, respectively.

The major groups in the MUR library were the delta subclass of the Proteobacteria ( $27 \%$ of the total clones), the Euryarchaeota (19\%) and the green non-sulfur bacteria $(14 \%)$. There were no clonal sequences belonging to the other subclasses of the Proteobacteria. The major groups in the TUR granule library were the Euryarchaeota (22\%), the Thermodesulfovibrio group 


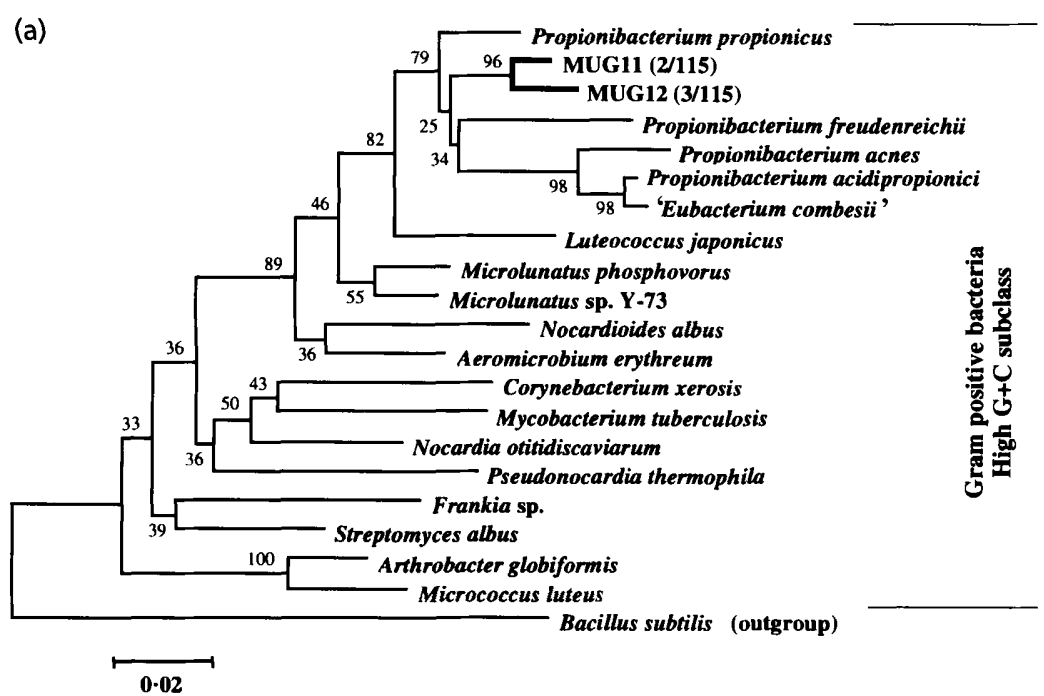

(b)

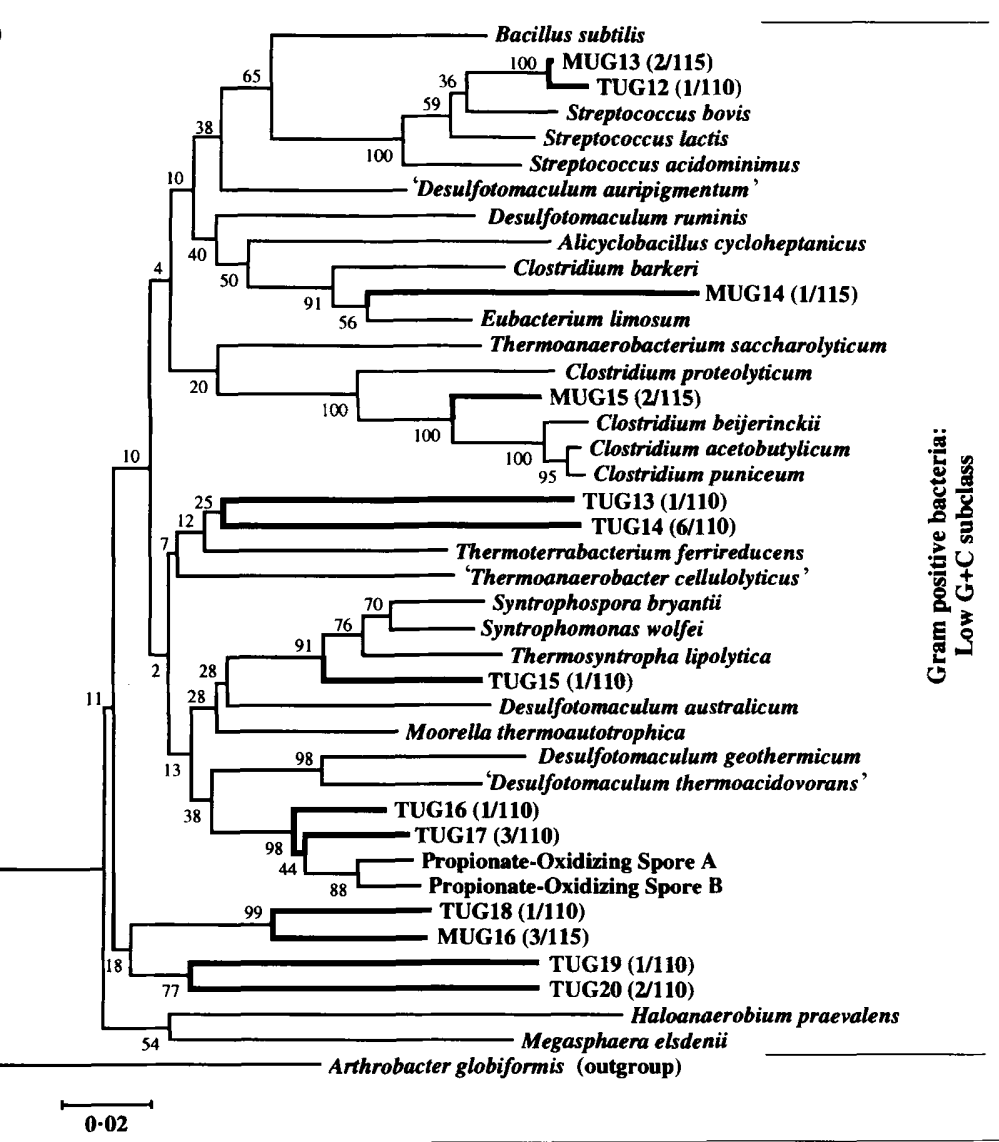

Fig. 3. Phylogenetic tree of the clones among the class Gram-positive bacteria of the domain Bacteria based on neighbourjoining analysis of partial 16S rDNA sequences. Numbers in parentheses and numbers at nodes are the same as in Fig. 1. Bacillus subtilis is represented as the outgroup of the tree among the high $G+C$ subclass (a) and Arthrobacter globiformis is used as the outgroup of the tree among the low $\mathrm{G}+\mathrm{C}$ subclass (b). (called 'paraphyletic assemblage' in the RDP; Maidak et al., 1997) (19\%), the green non-sulfur bacteria (18\%) and the low $\mathrm{G}+\mathrm{C}$ subclass of the Gram-positive bacteria (18\%) (Maidak et al., 1997) (Table 1). A significant difference between the two libraries was that a large number of $16 \mathrm{~S}$ rDNA sequences belonging to the class Proteobacteria were detected in the MUR granule clones, whereas, interestingly, there was no clonal sequence affiliated with the Proteobacteria in the TUR granule library. Moreover, the MUR clones were assigned to more diverse phylogenetic groups than the TUR clones.

\section{Archaea domain}

In the domain Archaea, we obtained three OTUs in each library (Fig. 1). All of these clones were assigned to the class Euryarchaeota, and all clones were close relatives of methanogens. Twenty completely identical sequences apparently belonging to Methanosaeta concilii (Patel \& 


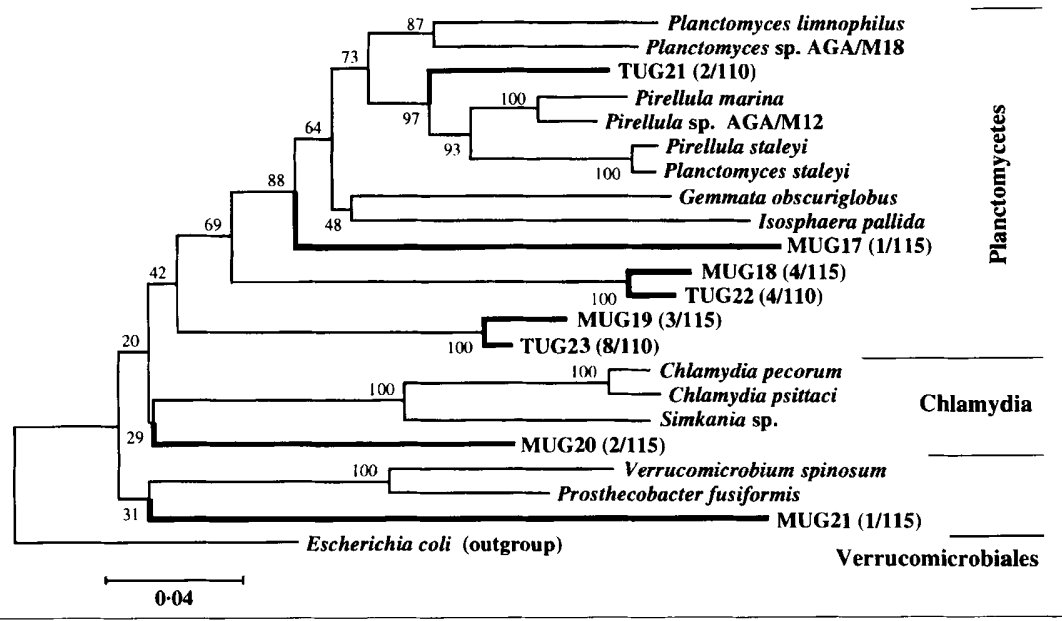

Fig. 4. Phylogenetic tree of the clones among the class Planctomyces and relatives of the domain Bacteria derived by neighbour-joining analysis of partial $16 \mathrm{~S}$ rDNA sequences. Numbers in parentheses and numbers at nodes are the same as in Fig. 1. E. coli is used as the outgroup.
Sprott, 1990) were detected in the MUR clones (MUG2). One clone showing $98.5 \%$ similarity to the $16 \mathrm{~S}$ rDNA of Methanosaeta concilii (MUG1), and one clone affiliated with the group Methanobacteriales (MUG3) were also detected in the MUR clones. In the TUR granule library, the most dominant sequence affiliated with the Archaea was closely related to Methanosaeta thermophila ('Methanothrix thermophila') (Kamagata et al., 1992) with $97 \cdot 2-97 \cdot 5 \%$ sequence similarity (TUG1 and TUG2, 20 clones). In addition, one OTU was recovered in the Methanobacteriales (TUG3, four clones), Methanobacterium thermoformicicum being the closest organism to the clones $(96.7 \%$ similarity).

\section{Bacteria domain}

(i) Green non-sulfur bacteria and relatives. We observed a number of clones affiliated with deeply branched groups in the domain Bacteria, the class green non-sulfur bacteria and the Thermodesulfovibrio group, at high frequencies in both MUR and TUR granule libraries (Fig. 2). Within the green non-sulfur bacteria, four and five OTUs, respectively, were detected from the MUR and TUR granule libraries at high frequencies (Table 1). Many of these clones (e.g. MUG6, TUG6) were related to the $16 \mathrm{~S}$ rDNA of unidentified eubacterium RB41 detected from sediment of a Carolina bay by $16 \mathrm{~S}$ rRNA gene analysis (Wise et al., 1997), with sequence similarities of $87-93 \%$. Some OTUs detected from each library were closely related to each other, although the adapted temperatures of the granules were different; e.g. MUG9 and TUG9 had $99.2 \%$ similarity. Within the Thermodesulfovibrio group, two OTUs were observed in each library (TUG4, 5 and MUG4, 5). The two OTUs (TUG4, 5) of the TUR clones had high degrees of relatedness to Thermodesulfovibrio yellowstonii (Henry et al., 1994) with 96.8-98.0\% sequence similarity. In addition, one OTU affiliated with the Synergistes clade was found in each library (MUG10, TUG11).

(ii) Gram-positive bacteria. In the class Gram-positive bacteria, six and nine OTUs were found in the MUR and TUR granule libraries, respectively (Fig. 3). In the high $\mathrm{G}+\mathrm{C}$ subclass, we observed only two OTUs from the
MUR clones. These clones were closely related to Propionibacterium species (Cummins \& Johnson, 1991). In the low $\mathrm{G}+\mathrm{C}$ subclass, four and nine OTUs were detected in the MUR and TUR clones, respectively. Two OTUs (MUG13, TUG12) detected from both libraries were closely related to Streptococcus bovis (Hardie \& Whiley, 1991) with $93 \cdot 1-93.6 \%$ similarity. One OTU (MUG15) from the MUR clones was a close relative of Clostridium acetobutylicum (Hippe et al., 1991) with $95.0 \%$ similarity. In the TUR library, one OTU (TUG15) was detected as a close relative of Thermosyntropha lipolytica (Svetlitshnyi et al., 1996) (93.2\% similarity), which is a thermophilic syntrophic fattyacid-oxidizing species, and two OTUs were found as closely related sequences to propionate-oxidizing spore formers A and B (TUG16, 17; 95.9-96.1\% similarity), which have been enriched as Gram-positive mesophilic, syntrophic propionate-oxidizing species (Harmsen, 1996). The remaining OTUs formed a clade with the low $\mathrm{G}+\mathrm{C}$ subclass, but there was no closely related relevant organism in the databases.

(iii) Planctomyces and relatives. Within the Planctomyces and relatives, including the Planctomyces, Chlamydia and Verrucomicrobiales subclasses (Maidak et al., 1997), five and three OTUs were found in the MUR and TUR libraries, respectively (Fig. 4). Within the Planctomyces subclass, we could retrieve several clones from both libraries, one of which (TUG21) from the TUR library could be a relative of the genus Pirellula. However, the remaining clones were phylogenetically distant from any reference organisms and were deeply branched within the group with relatively low bootstrap values. Within the Chlamydia and Verrucomicrobiales subclasses, one OTU was found in the MUR clones in both groups. However, there was no close relevant organism previously cultivated, and the bootstrap values of these clades were also quite low, suggesting that the affiliation of the OTUs cited above cannot be determined.

(iv) Cytophaga and relatives, and spirochaetes and relatives. In the class Cytophaga/Flexibacter/Bacteroides, we observed two OTUs only from the MUR library (MUG22, 23), to which the closest organism 


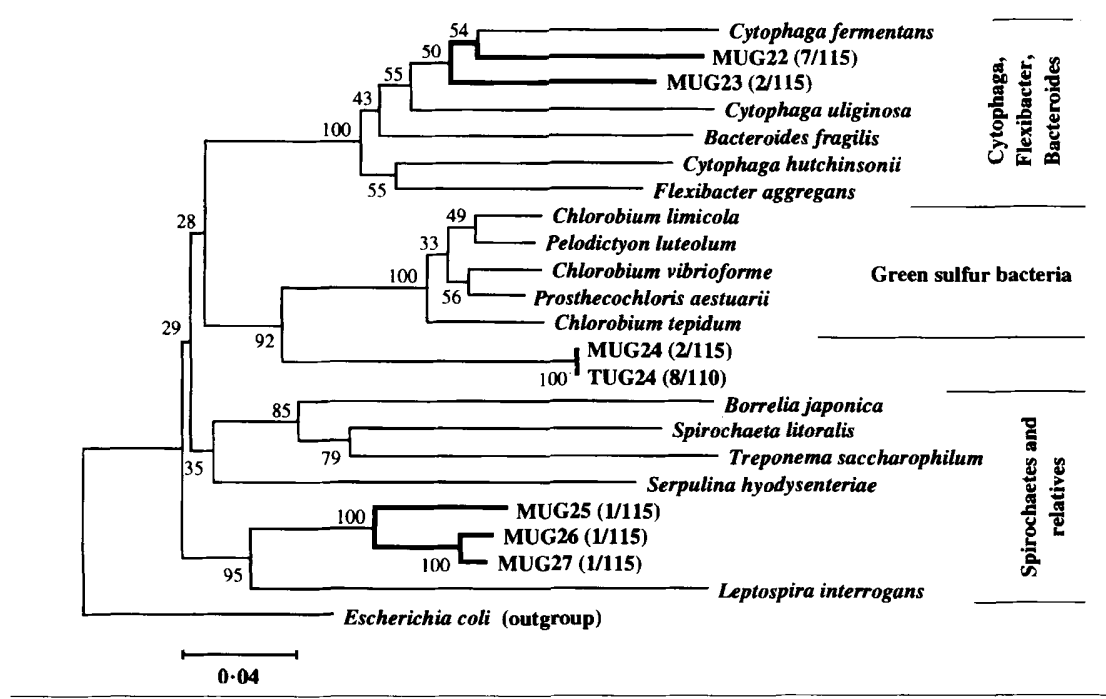

Fig. 5. Phylogenetic tree of the clones among the class Cytophaga/Flexibacterl Bacteroides, the spirochaetes and relatives and the green sulfur bacteria of the domain Bacteria derived by neighbour-joining analysis of partial 16S rDNA sequences. Numbers in parentheses and numbers at nodes are the same as in Fig. 1. E. coli is used as the outgroup.

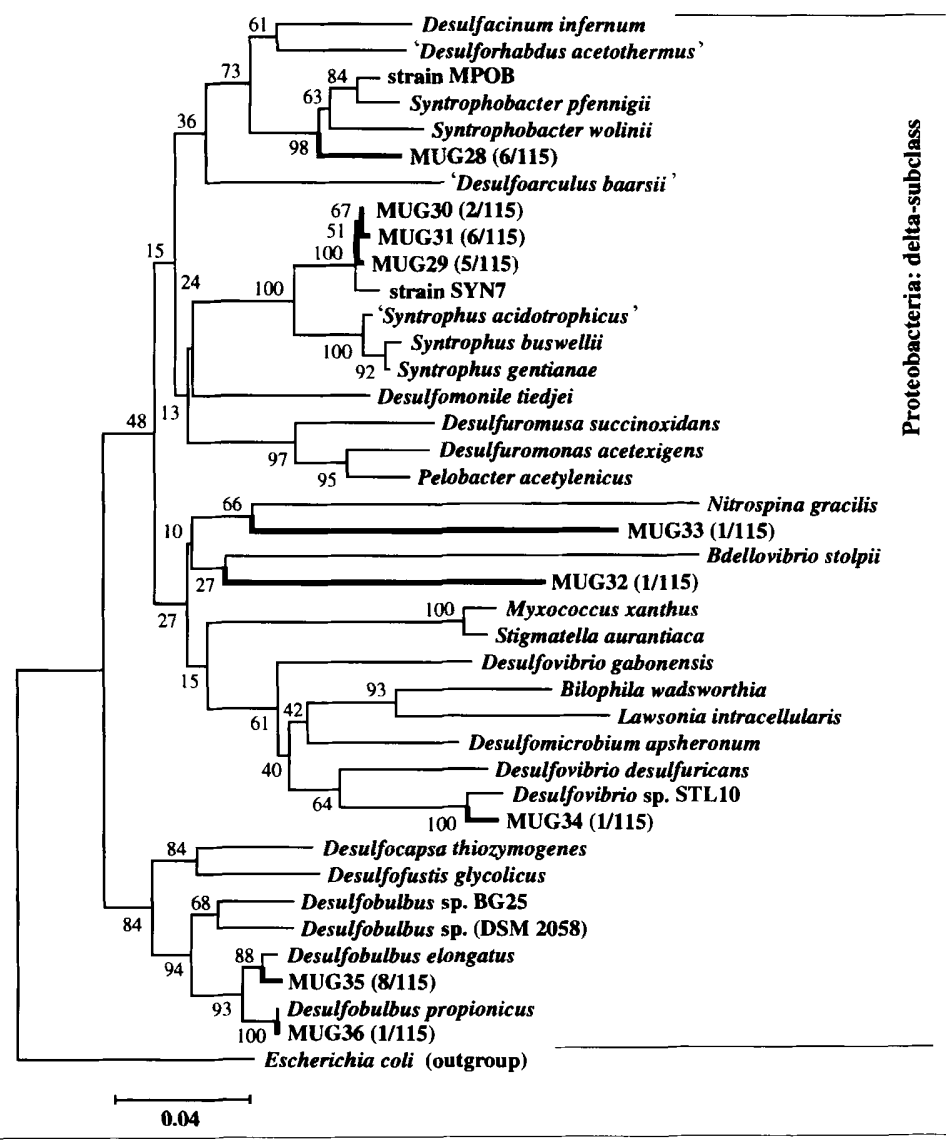

Fig. 6. Phylogenetic tree of the clones among the delta subclass of the Proteobacteria. Numbers in parentheses and numbers at nodes are the same as in Fig. 1. $E$. coli is used as the outgroup. was Cytophaga fermentans (Bachmann, 1955) with 87-4-87.5\% sequence similarity (Fig. 5). Nine clones were affiliated, and this fraction was the fourth predominant class in the MUR library. Within the class spirochaetes and relatives, three OTUs related to Leptospira species were found in the MUR clones (MUG25, 26, 27). Two OTUs (MUG 24, TUG 24) were affiliated with the class green sulfur bacteria with a $92 \%$ bootstrap value, but a relatively large evolutionary distance was estimated from hitherto-determined green sulfur bacterial species. (v) Proteobacteria: delta subclass. Within the class Proteobacteria, we were able to find a number of clones only in the MUR library (Fig. 6). All clone sequences in the Proteobacteria were located in the delta subclass. In this clade, all of the clones were relatively close to the reference organisms in the databases. Some of these sequences were closely related to sulfate-reducing organisms, e.g. Desulfovibrio species (MUG34, 99.3\% similarity), Desulfobulbus propionicus (Widdel \& Pfennig, 1982) (MUG36, 98.5\% similarity) and Desulfobulbus elongatus (Samain et al., 1984) (MUG35, 97.4\% simi- 
larity). One OTU was closely related to Syntrophobacter species (MUG28, 95.2\% with strain MPOB; Stams et al., 1993), with a relatively high number of clones (six clones). Three OTUs (MUG29, 30, 31) assigned to a strain SYN7 clade, which was enriched from a UASB granular sludge as a mesophilic, syntrophic propionateoxidizing strain (Harmsen, 1996; Harmsen et al., 1996), were detected at high frequency (19 clones). Two OTUs (MUG32, MUG33) were recovered in the delta subclass, but there was no close reference sequence in the databases.

\section{DISCUSSION}

The microbial constituents of mesophilic and thermophilic methanogenic granular sludges were studied by $16 \mathrm{~S}$ rDNA analysis. Granulation of both sludges occurred using wastewaters that contained very similar mixtures of defined substrates (sucrose; acetate; propionate; peptone or yeast extract) over 2 years operation. Although the seed sludge for each reactor was different, both performed high COD removal with methane formation at different temperatures, suggesting that both granular sludges contained micro-organisms necessary for complete mineralization of the substrates at different temperatures, i.e. both granules had the same function for COD removal.

For the construction of the $16 \mathrm{~S}$ rDNA clone libraries, we used a primer set that could amplify members of the domains Archaea and Bacteria simultaneously for PCR. To minimize bias introduced in the analysis (Farrelly et al., 1995; Suzuki \& Giovannoni, 1996), we used the following strategies: (1) bulk community DNAs were extracted from the granules taken from two different sites of the reactor and combined for use; (2) 16S rDNAs were amplified by PCR in triplicate PCR tubes containing the extracted bulk community DNA, then they were combined for cloning; (3) 15 PCR cycles were employed to minimize biases in the PCR step (Suzuki \& Giovannoni, 1996; Wilson \& Blitchington, 1996). Although it is impossible to remove all possible biases that might occur during DNA extraction, PCR amplification and cloning, all experimental conditions in these steps for the mesophilic and thermophilic granules were identical, hence the difference in the composition of $16 \mathrm{~S}$ rDNA sequence clones between the two granules could reflect the difference in microbial diversity in situ.

From this analysis, 22 (19\% of the total clones) and 24 $(22 \%)$ clonal $16 \mathrm{~S}$ rDNA sequences from the mesophilic and thermophilic granule clone libraries, respectively, were affiliated with the domain Archaea, and the remaining clones were assigned to the domain Bacteria. However, direct counts by in situ hybridization with an Archaea-specific probe (ARC915) (Stahl \& Amann, 1991) showed that the Archaea cells in the mesophilic and thermophilic granules comprised approximately 37 and $42 \%$ of the total cell number, respectively. The difference in the values between the cloning method and in situ hybridization enumeration might be due to the low efficiency of the lysis of hydrogenotrophic methanogens residing in both granules, although the cell number cannot be compared directly with the number of corresponding 16S rDNA sequences which were obtained. Epifluorescence microscopy revealed that a number of $\mathrm{F}_{420}$-autofluorescent curved rods morphologically similar to Methanobacterium were present. By using a pure culture of Methanobacterium thermoautotropbicum, it was found that the cells were not susceptible to lysis under the same conditions that we employed for the lysis of the granules (data not shown). The DNA extraction method employed here is milder than mechanical methods such as bead beating but we were concerned that vigorous extraction methods could lead to fragmentation of DNA strands due to shearing, which could have resulted in amplification of chimeric DNAs in the PCR step (Liesack et al., 1991). To avoid generating chimeric DNAs, we used a mild extraction method, which, however, could result in lysis bias. In fact, we could obtain only four clonal sequences close to the Methanobacteriales of the 110 sequences from the thermophilic granules, and only one close sequence of 115 sequences from the mesophilic granules. This suggests that the cloning strategy may have resulted in a limited estimate of diversity by the failure to obtain DNA from certain community members.

The mesophilic granule contained at least 36 different $16 \mathrm{~S}$ rDNA sequences within the microbial architecture and the thermophilic granule possessed at least 24 different sequences. From the cumulative number of different sequences plotted against the number of clones, we could estimate the difference in microbial diversity between the two granules (Fig. 7). We depicted approximate lines for the cumulative number of sequences versus the number of clones by calculating a simple parabola equation, $y=x /(a x+b)$, where $x=$ number of clones, $y=$ cumulative number of different sequences and $a, b=$ coefficients, and estimated the possible total number of different sequences from this equation, in which $y$ becomes $1 / a$ if $x$ was infinity. According to the calculations, the possible total number of sequences was estimated to be approximately 53 for the mesophilic granule and approximately 30 for the thermophilic granule. From this estimation, it is suggested that the microbial content in the mesophilic granules was almost twice as diverse as that of the thermophilic granule, although both of the granules had been exposed to similar substrates over 2 years operation.

In terms of microbial community structure, the difference between the two granules was clear. Major groups represented in the mesophilic clone library were the delta subclass of the Proteobacteria $(27 \%)$ and the Euryarchaeota (possibly methanogens, 19\%). In contrast, in the thermophilic clone library, the Euryarchaeota (possibly methanogens, 22\%), the Thermodesulfovibrio group (19\%), the green non-sulfur bacteria $(18 \%)$ and the low $\mathrm{G}+\mathrm{C}$ subclass of the Grampositive bacteria $(18 \%)$ were predominant groups. No thermophilic clone was recovered in the Proteobacteria, 


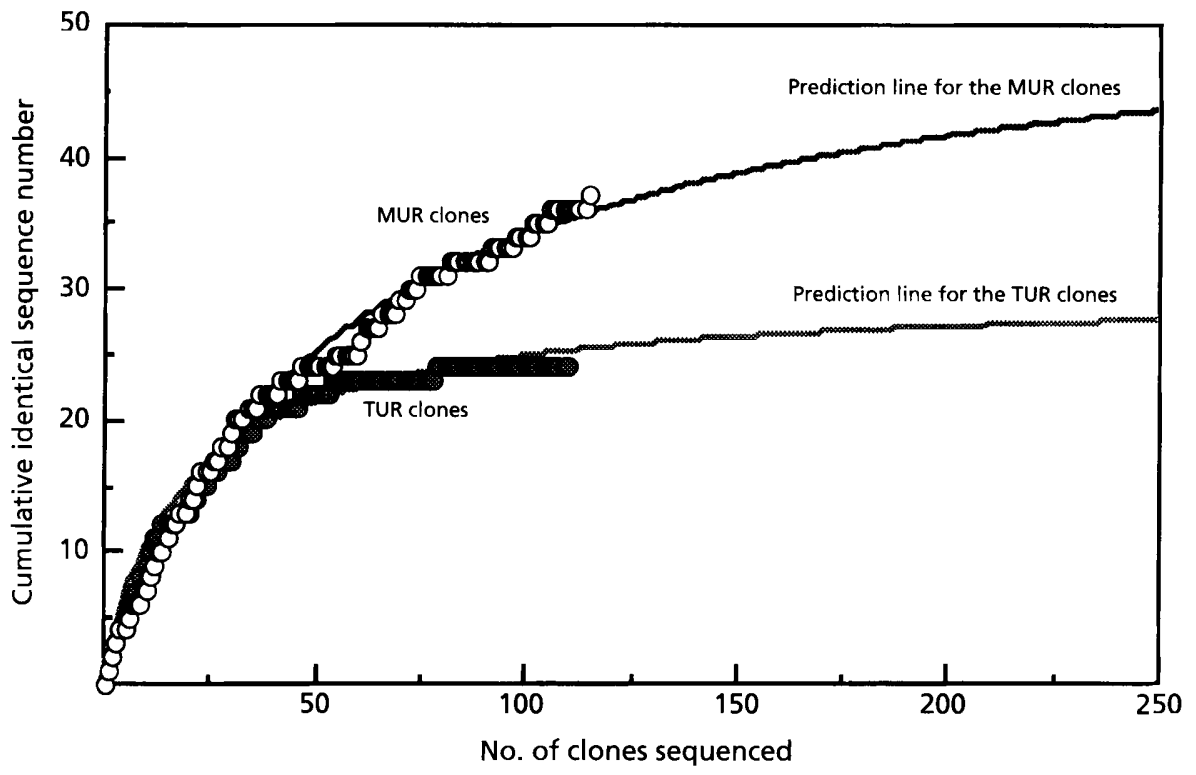

Fig. 7. Estimation of microbial diversities in the mesophilic and thermophilic granular sludges. The numbers of cumulative different $16 \mathrm{~S}$ rDNA sequences against the numbers of clones obtained were plotted for both of the sludges. Prediction of cumulative lines was performed by using a parabola equation, $y=x /(a x+b)$, where $y=$ cumulative number of different sequences, $x=$ number of clones made and $a, b=$ coefficients.

whereas this class was the most predominant group in the mesophilic clone library (Table 1).

With regard to the relationship between substrate composition and expected trophic groups in the reactors, both may contain the following major trophic groups: sugar (sucrose)-fermenting microbes, acetateutilizing microbes (acetoclastic methanogens), propionate-oxidizing microbes, microbes oxidizing other fermentation products (such as alcohols and fatty acids) and hydrogen (formate)-utilizing microbes (hydrogenotrophic methanogens). Although we should carefully avoid overinterpretation of data based solely on clonal sequences, we could find several clones closely related to the known trophic groups cited above, such as clones close to Methanosaeta concilii (Patel \& Sprott, 1990) and Methanosaeta thermophila (Kamagata et al., 1992) ('Methanothrix thermophila'), acetoclastic methane-producing methanogens, Methanobacterium thermoformicicum (Zhilina \& Ilarionov, 1985), a hydrogen-utilizing methanogen, Syntrophobacter (Boone \& Bryant, 1980) performing syntrophic propionate oxidation, an anaerobic syntrophic propionate-oxidizing species (SYN7) enriched from an UASB granule (Harmsen, 1996; Harmsen et al., 1996), some sulfatereducers and clostridia. However, the remaining clones, possibly affiliated with the green non-sulfur bacteria, the spirochaetes and relatives, Synergistes, and the Planctomyces and relatives, in both libraries were distinct from known organisms. Hence the functions of the microbes represented by these sequences are unknown.

Recently Godon et al. (1997) reported on 16S-rRNAbased molecular microbial diversity within anaerobic sludge used to treat wine distillation wastewater. They reported a large number of clones related to the green non-sulfur bacteria, the spirochaetes and relatives, Synergistes, and the Planctomyces and relatives as functionally unknown sequences. These types of sequences were also abundant in our clone libraries although our feed substrate was well-defined and much simpler, suggesting that the organisms represented by these sequences are certainly functioning as fundamental components in the anaerobic degradation of organic compounds.

Our study revealed the microbial composition and diversity of the mesophilic and thermophilic granules. Most importantly, the data suggest a large difference in microbial community structures between the two granules, and that the thermophilic granule has lower microbial diversity than the mesophilic granule. These findings could explain why thermophilic anaerobic processes are more susceptible to environmental changes than mesophilic processes (van Lier, 1996). Such elasticity in the mesophilic granule could be supported by the quite diverse microbes which contain multiple genera and species with the same metabolic functions. As the database continues to expand, we will be able to further elucidate the community structures of anaerobic sludge granules.

\section{ACKNOWLEDGEMENTS}

We thank Satoshi Hanada for his helpful suggestion for performing the phylogenetic analysis and his critical reading of the manuscript. We also thank Takema Fukatsu and 
Kazutaka Yamada for their advice on several molecular techniques.

\section{REFERENCES}

Altschul, S. F., Gish, W., Miller, W., Myers, E. W. \& Lipman, D. J. (1990). Basic local alignment search tool. J Mol Biol 215, 403-410.

Amann, R. I., Binder, B. J., Olson, R. J., Chisholm, S. W., Devereux, R. \& Stahl, D. A. (1990). Combination of $16 \mathrm{~S}$ rRNA-targeted oligonucleotide probes with flow cytometry for analyzing mixed microbial populations. Appl Environ Microbiol 56, 1919-1925.

Bachmann, B. J. (1955). Studies on Cytophaga fermentans, n. sp., a facultatively anaerobic lower myxobacterium. J Gen Microbiol 13, 541-551.

Boone, D. R. \& Bryant, M. P. (1980). Propionate-degrading bacterium, Syntrophobacter wolinii sp. nov. gen. nov., from methanogenic ecosystems. Appl Environ Microbiol 40, 626-632.

Cummins, C. S. \& Johnson, J. J. (1991). The genus Propionibacterium - nonmedical. In The Prokaryotes, pp. 834-850. Edited by A. Balows, H. G. Trüper, M. Dworkin, W. Harder \& K.-H. Schleifer. New York: Springer.

Farrelly, V., Rainey, F. A. \& Stackebrandt, E. (1995). Effect of genome size and $r r n$ gene copy number on PCR amplification of $16 \mathrm{~S}$ rRNA genes from a mixture of bacterial species. Appl Environ Microbiol 61, 2798-2801.

Felsenstein, J. (1985). Confidence limits of phylogenies: an approach using the bootstrap. Evolution 39, 783-791.

Godon, J.-J., Zumstein, E., Dabert, P., Habouzit, F. \& Moletta, R. (1997). Molecular microbial diversity of an anaerobic digestor as determined by small-subunit rDNA sequence analysis. Appl Environ Microbiol 63, 2802-2813.

Grotenhuis, J. T. C., Smit, M., Plugge, C. M., Yuansheng, X., van Lammeren, A. A. M., Stams, A. J. M. \& Zehnder, A. J. B. (1991). Bacteriological composition and structure of granular sludge adapted to different substrate. Appl Environ Microbiol 57, 1942-1949.

Hardie, J. M. \& Whiley, R. A. (1991). The genus Streptococcus oral. In The Prokaryotes, pp. 1421-1449. Edited by A. Balows, H. G. Trüper, M. Dworkin, W. Harder \& K.-H. Schleifer. New York: Springer.

Harmsen, H. J. M. (1996). Detection, phylogeny and population dynamics of syntrophic propionate-oxidizing bacteria in anaerobic granular sludge. $\mathrm{PhD}$ thesis, Wageningen Agricultural University.

Harmsen, H. J. M., Kengen, H. M. P., Akkermans, A. D. L., Stams, A. J. M. \& de Vos, W. M. (1996). Detection and localization of syntrophic propionate-oxidizing bacteria in granular sludge by in situ hybridization using $16 \mathrm{~S}$ rRNA-based oligonucleotide probes. Appl Environ Microbiol 62, 1656-1663.

Henry, E. A., Devereux, R., Maki, J. S., Gilmour, C. C., Woese, C. R., Mandelco, L., Schauder, R., Remsen, C. C. \& Mitchell, R. (1994). Characterization of a new thermophilic sulfate-reducing bacterium Thermodesulfovibrio yellowstonii, gen. nov. and sp. nov.: its phylogenetic relation to Thermodesulfobacterium commune and their origins deep within the bacterial domain. Arch Microbiol 161, 62-69.

Hippe, H., Andreesen, J. R. \& Gottschalk, G. (1991). The genus Clostridium - nonmedical. In The Prokaryotes, pp. 1800-1866. Edited by A. Balows, H. G. Trüper, M. Dworkin, W. Harder \& K.-H. Schleifer. New York: Springer.

Kamagata, Y., Kawasaki, H., Oyaizu, H., Nakamura, K., Mikami, E., Endo, G., Koga, Y. \& Yamasato, K. (1992). Characterization of three thermophilic strains of Methanothrix ('Methanosaeta') thermophila sp. nov. and rejection of Methanothrix ('Methanosaeta') thermoacetophila. Int J Syst Bacteriol 42, 463-468.

Kumar, S., Tomura, K. \& Nei, M. (1993). MEGA: Molecular Evolutionary Genetics Analysis, version 1·0. University Park: The Pennsylvania State University.

Lane, D. J. (1991). 16S/23S rRNA sequencing. In Nucleic Acid Techniques in Bacterial Systematics, pp. 115-175. Edited by E. Stackebrandt \& M. Goodfellow. Chichester: Wiley.

Lettinga, G. (1995). Anaerobic digestion and wastewater treatment systems. Antonie Leeuwenhoek 67, 3-28.

van Lier, J. B. (1996). Limitations of thermophilic anaerobic wastewater treatment and the consequences for process design. Antonie Leeuwenhoek 69, 1-14.

Liesack, W., Weyland, H. \& Stackebrandt, E. (1991). Potential risks of gene amplification by PCR as determined by $16 \mathrm{~S}$ rDNA analysis of a mixed-culture of strict barophilic bacteria. Microb Ecol 21, 191-198.

Macario, A. J. L., Visser, F. A., van Lier, J. B. \& Conway de Macario, E. (1991). Topography of methanogenic subpopulations in a microbial consortium adapting to thermophilic conditions. J Gen Microbiol 137, 2179-2189.

MacLeod, F. A., Guiot, S. R. \& Costerton, J. W. (1990). Layered structure of bacterial aggregates produced in an upflow anaerobic sludge bed and filter reactor. Appl Environ Microbiol 56, 1598-1607.

Maidak, B. L., Olsen, G. J., Larsen, N., Overbeek, R., McCaughey, M. J. \& Woese, C. R. (1997). The RDP (Ribosomal Database Project). Nucleic Acids Res 25, 109-110.

Ohkuma, M. \& Kudo, T. (1996). Phylogenetic diversity of the intestinal bacterial community in the termite Reticulitermes speratus. Appl Environ Microbiol 62, 461-468.

Patel, G. B. \& Sprott, G. D. (1990). Methanosaeta concilii gen. nov., sp. nov. ('Methanothrix concilii') and Methanosaeta thermoacetophila nom. rev., comb. nov. Int J Syst Bacteriol 40, 79-82.

Saito, N. \& Nei, M. (1987). The neighbor-joining method: a new method for constructing phylogenetic trees. Mol Biol Evol 4, 406-425.

Samain, E., Dubourguier, H. C. \& Albagnac, G. (1984). Isolation and characterization of Desulfobulbus elongatus sp. nov. from a mesophilic industrial digester. Syst Appl Microbiol 5, 391-401.

Schmidt, J. E. \& Ahring, B. K. (1995). Granulation in thermophilic upflow anaerobic sludge blanket (UASB) reactors. Antonie Leeuwenhoek 68, 339-344.

Stahl, D. A. \& Amann, R. (1991). Development and application of nucleic acid probes. In Nucleic Acid Techniques in Bacterial Systematics, pp. 205-248. Edited by E. Stackebrandt \& M. Goodfellow. Chichester: Wiley.

Stams, A. J. M., Grotenhuis, J. T. C. \& Zehnder, A. J. B. (1989). Structure-function relationship in granular sludge. In Recent Advances in Microbial Ecology, pp. 440-445. Edited by T. Hattori, Y. Ishida, Y. Maruyama, R. Y. Morita \& A. Uchida. Tokyo: Japan Scientific Society.

Stams, A. J. M., Grolle, K. C. F., Frijters, C. T. M. J. \& van Lier, J. B. (1992). Enrichment of thermophilic propionate-oxidizing bacteria in syntrophy with Methanobacterium thermoautotrophicum or Methanobacterium thermoformicicum. Appl Environ Microbiol 58, 346-352.

Stams, A. J. M., van Dijk, J. B., Dijkema, C. \& Plugge, C. M. (1993). Growth of syntrophic propionate-oxidizing bacteria with fumarate in the absence of methanogenic bacteria. Appl Environ Microbiol 59, 1114-1119. 
Suzuki, M. T. \& Giovannoni, S. J. (1996). Bias caused by template annealing in the amplification of mixtures of $16 \mathrm{~S}$ rRNA genes by PCR. Appl Environ Microbiol 62, 625-630.

Svetlitshnyi, V., Rainey, F. \& Wiegel, J. (1996). Thermosyntropha lipolytica gen. nov., sp. nov., a lipolytic, anaerobic, alkalitolerant, thermophilic bacterium utilizing short- and long-chain fatty acids in syntrophic coculture with a methanogenic archaeum. Int J Syst Bacteriol 46, 1131-1137.

Thompson, J. D., Higgins, D. G. \& Gibson, T. J. (1994). CLUSTAL W : improving the sensitivity of progressive multiple sequence alignment through sequence weighting, position-specific gap penalties and weight matrix choice. Nucleic Acids Res 22, 4673-4680.

Tsai, Y.-L. \& Olson, B. H. (1991). Rapid method for direct extraction of DNA from soil and sediments. Appl Environ Microbiol 57, 1070-1074.

Ward, D. M., Weller, R. \& Bateson, M. M. (1990). 16S rRNA sequences reveal numerous uncultured microorganisms in a natural community. Nature 345, 63-65.

Weisburg, W. G., Barns, S. M., Pelletier, D. A. \& Lane, D. J. (1991). $16 \mathrm{~S}$ ribosomal DNA amplification for phylogenetic study. $J$ Bacteriol 173, 697-703.

Widdel, F. \& Pfennig, N. (1982). Studies on dissimilatory sulfatereducing bacteria that decompose fatty acids. II. Incomplete oxidation of propionate by Desulfobulbus propionicus gen. nov., sp. nov. Arch Microbiol 131, 360-365.
Wiegant, W. M. (1986). Thermophilic anaerobic digestion for waste and wastewater treatment. $\mathrm{PhD}$ thesis, Wageningen Agricultural University.

Wilson, K. H. \& Blitchington, R. B. (1996). Human colonic biota studied by ribosomal DNA sequence analysis. Appl Environ Microbiol 62, 2273-2278.

Wise, M. G., McArthur, J. V. \& Shimkets, L. J. (1997). Bacterial diversity of a Carolina bay as determined by $16 \mathrm{~S}$ rRNA gene analysis: confirmation of novel taxa. Appl Environ Microbiol 63, 1505-1514.

Woese, C. R. (1987). Bacterial evolution. Microbiol Rev 51, 221-271.

Woese, C. R., Kandler, O. \& Wheelis, M. L. (1990). Towards a natural system of organisms: proposal for the domains Archaea, Bacteria, and Eucarya. Proc Natl Acad Sci USA 87, 4576-4579.

Wu, W.-M., Jain, M. K., Conway de Macario, E., Thiele, J. H. \& Zeikus, J. G. (1992). Microbial composition and characterization of prevalent methanogens and acetogens isolated from syntrophic methanogenic granules. Appl Microbiol Biotechnol 38, 282-290.

Zhilina, T. N. \& llarionov, S. A. (1985). Characteristics of formateassimilating methane bacteria and description of Methanobacterium thermoformicicum sp. nov. Microbiology (English translation of Mikrobiologiya) 53, 647-651.

Received 4 March 1998; revised 12 May 1998; accepted 19 May 1998. 